\title{
GERMINATION AND DESSICATION OF Hancornia speciosa Gomes SEEDS
}

\section{GERMINAÇÃO E SECAGEM DE SEMENTES DE Hancornia speciosa Gomes}

\section{Daiane Mugnol DRESCH ${ }^{1}$; Tatiane Sanches JEROMINI²; Silvana de Paula Quintão SCALON ${ }^{3 *}$; Rosilda Mara MUSSURY ${ }^{4}$; Tathiana Elisa MASETTO³ Zefa Valdivina PEREIRA ${ }^{4}$}

1. Pós-Doutoranda em Agronomia, Universidade Federal da Grande Dourados - UFGD, Dourados, MS, Brasil; 2. Bolsista de Iniciação científica, acadêmica de Agronomia, UFGD; 3. Docentes da Faculdade de Ciências Agrárias, UFGD, Dourados, MS, Brasil. * Bolsista de Produtividade em Pesquisa do CNPq, email: silvanascalon@ufgd.edu.br; 4. Docentes da Faculdade de Ciências Biológicas e Ambientais, UFGD, MS. Brasil.

\begin{abstract}
The aim of this work was describe the germination and evaluate the desiccation and reduction in desiccation sensitivity of Hancornia speciosa Gomes seeds. Initially, we evaluated the germination characteristics and morphophysiological aspects of seedlings. The seeds in the first experiment were subjected to fast desiccation (activated silica gel) and slow desiccation (laboratory conditions) until the water content reached $40 \%, 30 \%, 20 \%$, and $15 \% \pm 2 \%$. To reduce the desiccation sensitivity, in the second experiment, the seeds were soaked in polyethylene glycol (PEG) at potentials of - 0.1 and $0.3 \mathrm{MPa}$ for $120 \mathrm{~h}$, with or without abscisic acid (ABA) $\left(10^{-4} \mu \mathrm{M}\right)$, and subsequently subjected to fast desiccation until a water content of $15 \%$ was reached, based on the results from the first experiment. The seed vigor in both experiments was evaluated by the primary root protrusion tests, percentage of normal seedlings, germination speed index, length and mass (shoot, underground, and total). Seedlings of $H$. speciosa feature a stem-like xylopodium structure. The seeds were tolerant to water reduction up to $15 \%$ by fast desiccation and $30 \%$ by slow desiccation. Moreover, priming was not efficient in reducing the desiccation sensitivity of $H$. speciosa seeds.
\end{abstract}

KEYWORDS: Mangaba. Drying time. Polyethylene glycol. Abscisic acid.

\section{INTRODUCTION}

The Brazilian Savanna has a wide range of climate, terrains and soils, which allows for a wide range of vegetation (OLIVEIRA FILHO; RATTER, 2002). From the standpoint of biological diversity, Brazilian Savanna is recognized as the richest savanna in the world, hosting 11,627 already cataloged native plant species (M.M.A., 2013).

Among the many species present in the Brazilian Savanna, Hancornia speciosa Gomes, popularly known as "mangaba" stands out and grows naturally in the Southeast, Northeast, and Midwest regions of Brazil. Its fruits can be freshly consumed or used to make juices, ice cream, and jelly (SOUZA et al., 2007). However, populations of this species have been reduced due to unsustainable exploitation and deforestation of these regions (BARROS et al., 2006), which hinders its propagation primarily by seeds. The seeds of this species are sensitive to desiccation, which complicates its ex-situ conservation, i.e., in seed banks (MASETTO; SCALON, 2014). Therefore, it is necessary to develop techniques that enable the conservation and maintenance the seed viability and to undertake studies on the morphological aspects of germination to understand the germination process, facilitating its propagation in nurseries.
Understanding the morphological aspects of germination contributes to the propagation of the species, as it addresses the classification of germination relative to the position of cotyledons. This in turn, helps to interpret and standardize germination tests, thereby contributing to the integral morpho-anatomical knowledge of the species. Often, prolonged germination and/or slow initial seedling development are inherent behaviors of the species, but they are little known and therefore not taken into account during the planning and production processes (ABUD et al., 2009).

Studies of desiccation tolerance in seeds are important for $e x$-situ conservation of germplasm of native fruit species from the Brazilian Savanna to indicate the efficient levels of water for seed storage, without causing damage to the physiological quality and further propagation of the species (SCALON et al., 2012). The main challenge for the ex-situ seed conservation of desiccationsensitive species is determining its behavior to desiccation, whether its sensitivity or storage is possible for only a short period of time (typically in the order of weeks to months) (DAWS et al., 2006). However, the major factor affecting sensitivity to desiccation is the desiccation rate (KERMODE and FINCH-SAVAGE, 2002; BERJAK and PAMMENTER, 2008). 
It has been reported that fast desiccation of whole seeds results in lower water contents without altering seed viability, because there is not enough time for deleterious reactions to progress, which would cause loss of viability in desiccationintolerant material (BERJAK et al., 1990, PRITCHARD, 1991). During slow desiccation, the seeds are exposed to hydration periods that allow the occurrence of deleterious reactions, including those caused by free radicals (BERJAK et al., 1993).

Besides the reduction in seed metabolism, the use of priming with polyethylene glycol (PEG) and abscisic acid (ABA), when applied alone, together, or in combination with other stress agents such as desiccation, are able to induce or increase the tolerance to desiccation in recalcitrant seeds (BEARDMORE; WHITTLE, 2005; ANDRÉO et al., 2006) and germinated orthodox seeds (BUITINK et al., 2003; FARIA et al., 2005).

Given the difficulties and need formain taining the germplasm of tropical species due to threats to Brazilian savanna biodiversity, the knowledge of the morphological and anatomical aspects of early development and desiccation of seeds are important to provide information about the germination process and aid in the propagation and conservation of the species. 1) the species has a subterranean system with xylopodium, which is typical for the Brazilian savanna species; (2) due to the environmental conditions, the seeds of $H$. speciosa tolerate desiccation of up to $15 \%$ water content regardless of the type of desiccation. To test these hypotheses, we aimed to describe the germination, evaluate the effects of desiccation and reduction insensitivity to desiccation of $H$. speciosa seeds through priming with polyethylene glycol and abscisic acid.

\section{MATERIAL AND METHODS}

The fruits of Hancornia speciosa Gomes were collected at the beginning of the ripening period in October 2013, from 15 matrices from the city of Brasília-DF. After collection, the fruits were brought to the Laboratory of Plants Nutrition and Metabolism, Federal University of Grande Dourados, (UFGD), Dourados-MS, where they were washed with running water, discarding any damaged fruits. Subsequently, fruits were processed manually and with sieves to separate the seeds from the fruit residue. Then, the seeds were washed and placed on Germitest ${ }^{\circledR}$ paper for $20 \mathrm{~min}$ at room temperature $\left(25 \pm 2{ }^{\circ} \mathrm{C}, 35 \%\right.$ relative humidity).

\section{Seed germination}

The germination characteristics were assessed by soaking the seeds until the emergence of the first pair of formed leaves from cotyledons. For germination, seeds were sown on three sheets of Germitest ${ }^{\circledR}$ paper moistened with distilled water in quantities equivalent to 2.5 times the mass of dry paper, and the test was conducted in a biochemical oxygen demand (B.O.D.) chamber at constant temperature of $25^{\circ} \mathrm{C}$. The different stages of seedling development were followed by fixation of the material in formaldehyde-acetic acid-alcohol (FAA) 50 and subsequent storage in $70 \%$ alcohol and then they were drawn using a camera lucida.

To study the anatomy of the xylopodium median, cross sections were made freehand, clarified with $20 \%$ sodium hypochlorite, and after washing in $2 \%$ acetic water, they were subjected to double staining with astra blue and safranin and mounted in glycerin gelatin (DOP e GAUTIÉ, 1928). After examining the slide collection, the plant material was documented by photomicrographs, using a binocular microscope with attached camera Moticam 2300 3.0MP and accompanying Motic Images Plus image capture program (Motic, Richmond, BC, Canada).

\section{Experiment I: Seed desiccation}

Seeds were subjected to fast desiccation on activated silica gel $(8 \% \mathrm{RH})$ and slow desiccation conditions in a laboratory environment $\left(25 \pm 2{ }^{\circ} \mathrm{C}\right.$ and $35 \% \mathrm{RH}$ ) until they reached a water content of $40 \%, 30 \%, 20 \%$, and $15 \%$; seeds of $H$. speciosa do not tolerate desiccation below $15 \%$ water content (BARROS et al., 2006; SANTOS et al., 2010; MASETTO; SCALON, 2014).

For fast desiccation, the seeds were placed on a metal screen inside 'germ box'-type plastic boxes covered with silica gel at the bottom. The silica was replaced as soon as the surface layer lost the indicative blue color. In slow desiccation, the seeds were conditioned in open plastic containers at a temperature of $25 \pm 2{ }^{\circ} \mathrm{C}$ and $35 \% \mathrm{RH}$. The seeds were weighed every hour until they reached the preestablished water content levels, calculated according to the formula by Sacandé et al. (2004). After obtaining the desired water content by the two desiccation methods, seeds were pre-humidified in a humid chamber $\left(25^{\circ} \mathrm{C}, 100 \% \mathrm{RH}\right.$, under continuous light) for $24 \mathrm{~h}$ to prevent damage by soaking, and then the following characteristics were determined to assess the seed vigor:

Water content was determined at $105^{\circ} \mathrm{C} \pm$ $3^{\circ} \mathrm{C}$ for $24 \mathrm{~h}$ using the oven-drying (BRASIL, 2009) 
with three replicates of $5 \mathrm{~g}$ of seeds each, expressed as percentage on a fresh weight basis.

Protrusion of the primary root was measured on Germitest ${ }^{\circledR}$ paper rolls with four replications of 25 seeds each, germinated with B.O.D. (Biochemical Oxygen Demand) at $25^{\circ} \mathrm{C}$ under continuous white light. Assessments were conducted daily, and the root was considered protruded when it reached a length of $5 \mathrm{~mm}$. The results were expressed in percentages $(\%)$.

Percentage of normal seedlings: seeds were held in Germitest ${ }^{\circledR}$ paper rolls and kept in B.O.D. type germination boxes at a constant temperature of $25{ }^{\circ} \mathrm{C}$ under white light. Evaluations were performed $30 \mathrm{~d}$ after sowing, when it was possible to verify the degree of germination. The percentage of normal seedlings was calculated using the emission of developed aerial and underground systems (root + xylopodium + cotyledon) as the criteria, and the data were expressed as a percentage $(\%)$.

Germination speed index (GSI) calculated using the numbers of seedlings that germinated each day divided by the numbers of days between sowing and germination, according to the formula proposed by Maguire (1962).

Seedling length was obtained by measuring the shoot, underground systems (root + xylopodium + cotyledon) and total lengths seedlings using a millimeter ruler. The results were expressed in centimeters $(\mathrm{cm})$.

Dry mass was obtained by measuring the shoot, underground systems (root + xylopodium + cotyledon) and total seedlings that had been dried in an oven at $60^{\circ} \mathrm{C}$ for 48 hours using an analytical balance $(0.0001 \mathrm{~g})$, with the results expressed in grams $(\mathrm{g})$.

The experimental design that followed was completely randomized with a factorial arrangement (five water contents $\times$ two types of desiccation), with four replicates of 25 seeds each; data were subjected to analysis of variance and regression analysis at $5 \%$ probability and $\mathrm{R}^{2}$ greater than or equal to 0.45 using SISVAR software.

\section{Experiment II: Reduced sensitivity to desiccation}

To study the effect of PEG and ABA on reduction of sensitivity to seed desiccation, seeds were soaked in PEG-6000 at osmotic potentials of 0.1 and $-0.3 \mathrm{MPa}$ for $120 \mathrm{~h}$, with or without ABA $\left(10^{-4} \mu \mathrm{M}\right)$ for 120 hours. After then, the seeds were washed in running water to remove excess solution and dried on a paper towel surface. The seeds were then subjected to desiccation to a minimum of $50 \%$ of normal seedlings, based on the results of the first experiment. The seed vigor was evaluated according to the tests mentioned in Experiment I.

The experimental design was completely randomized and data were subjected to analysis of variance to compare the means using the ScottKnott test implemented in the SISVAR software.

\section{RESULTS}

The initial morphology of the seedlings was hypogeal. Germination was lowly initiated by radicle protrusion, which resembles a callus (Figure $1 \mathrm{~B})$.

Hypocotyl tuberization occurred dearly in the development of the underground system, featuring xylopodium (Figure 1C) with a predominantly stem-like structure (Figure 1). Later, the epicotyl elongates (Figure 1D) displayed the first pair of opposite and simple protophylls (Figure 1E). Thereafter, the first pair of eophylls, also opposite and simple with short petiole and without stipules (Figure 1F, G), as well as mesophylls, are produced. The root system was simple, consisting of primary root and few (Figure $1 \mathrm{H}$ ) thin, short, tender, cylindrical secondary roots of the same color as the primary root.

The slow desiccation (under laboratory conditions) of $H$. speciosa seeds took more than 39 $\mathrm{h}$ to reach $15 \%$ water content. However, it was found that fast desiccation (by silica gel) occurred in shorter span of time; requiring only $29 \mathrm{~h}$ to reach the same water content (Figure 2A).

The radicle protrusion is affected by slow desiccation of seeds, decreasing linearly with the water content from the initial $86 \%$ (freshly processed) to $48 \%$ in seeds with the lowest water content $(15 \%)$. In seeds exposed to fast desiccation, there was no variation in radicle protrusion between seeds with different water contents, with an average value of $72 \%$ (Figure 2B).

The percentage of normal seedlings was reduced by the desiccation methods. The best results $(72 \%)$ were observed in newly processed seeds (water content $48 \%$, Figure 2C). However, it is noteworthy that with fast desiccation to water content of $15 \%$, the percentage of normal seedlings was $55 \%$, where as slow desiccation rendered the percentage of normal seedlings to $42 \%$. The germination speed index was not significantly different between the types of desiccation, but differed between seeds with different water content, the germination speed decreased linearly with the water content (Figure 2D). 


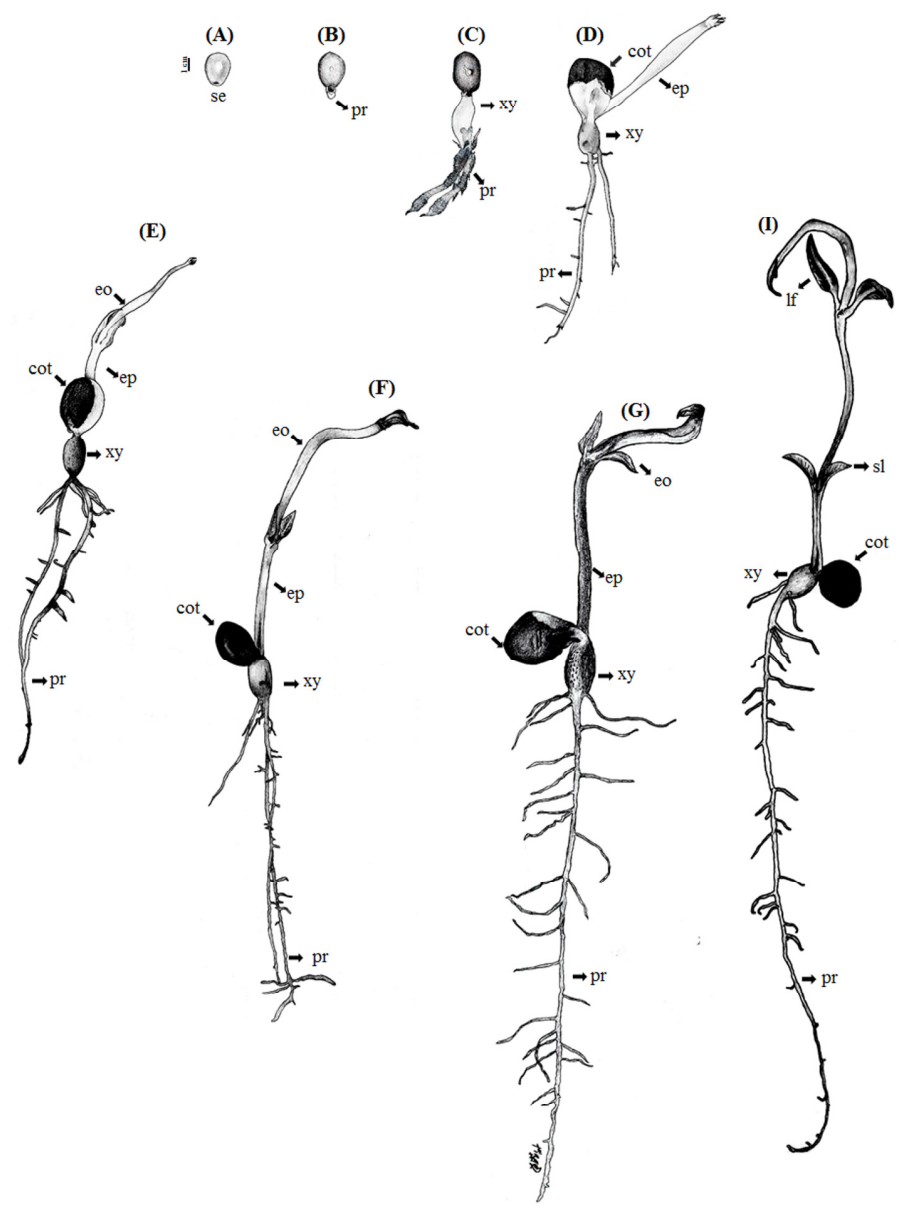

Figure 1. Morphological aspects of Hancornia speciosa seeds and seedlings A- Seed; B-I - seedlings development aspects. se: seeds, pr: primary root, xy: xylopodium; cot: cotyledon, ep: epicotyl, eo: eophyll, sl: scale leaf and lf: leaf.

A)

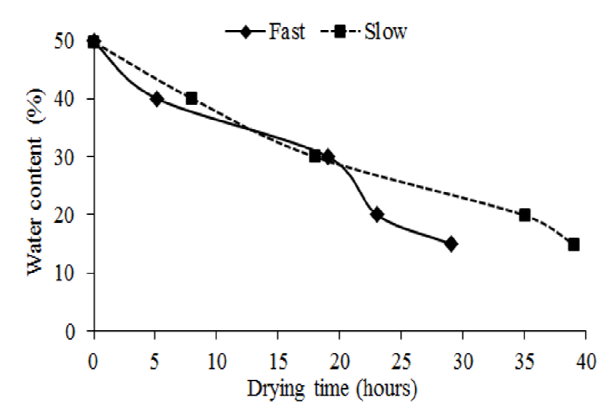

C)

- (‥) Slow $\mathrm{y}=29.7073+0.8679 \mathrm{x} ; \mathrm{R}^{2}=0.63$

- (-) Fast $y=56.5421+0.2872 x ; R^{2}=0.47$

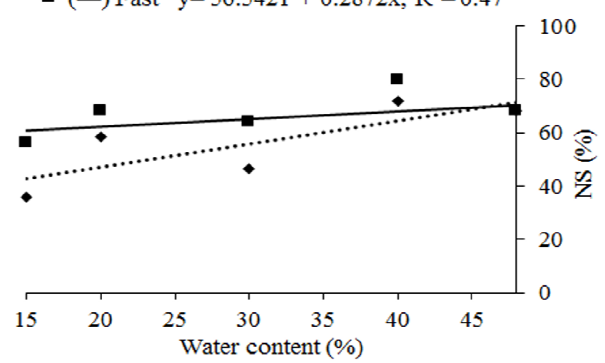

B)

- (․) Slow $\mathrm{y}=29.9482+1.1738 \mathrm{x} ; \mathrm{R}^{2}=0.79$

- Fast $\mathrm{y}=$ without adjustment

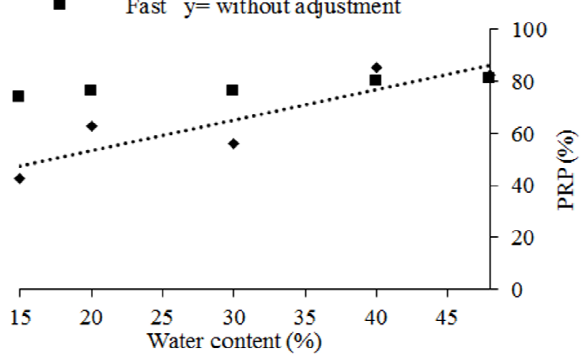

D)

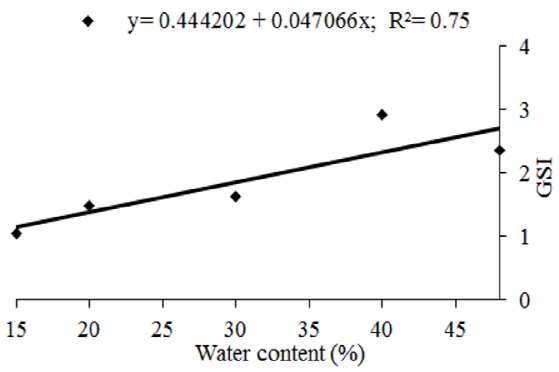

Figure 2. Drying time of seeds (A), primary root protrusion (PRP) (B), percentage of normal seedlings (NS) (C), germination speed index (GSI) (D) of Hancornia speciosa seeds subjected to fast and slow drying at different water contents. 
The slow desiccation adversely affected the shoot length, and the lowest growth was observed at $15 \%$ water content $(4.88 \mathrm{~cm})$, where as there was no correlation in fast desiccation (Figure 3A). The underground system length and the total length of seedlings were significantly correlated only to the water content, with lower values observed at $15 \%$ water content $(7.72$ and $13.54 \mathrm{~cm}$ ) (Figures $3 \mathrm{~B}$ and 3C). For shoot dry mass not significantly differ between the types of desiccation, but it differed among the water contents, with the highest results observed in the newly processed seeds $(0.0145 \mathrm{~g})$ (Figure 3D). The underground system dry mass did not significantly differ between the factors, with the overall average of $0.0568 \mathrm{~g}$. Fast desiccation provided the highest accumulation of total dry biomass at water content of $30 \%(0.5040 \mathrm{~g})$, and after slow desiccation, the highest accumulation of biomass occurred at water content of $15 \%(0.0556 \mathrm{~g})$ (Figure 3E).
A)

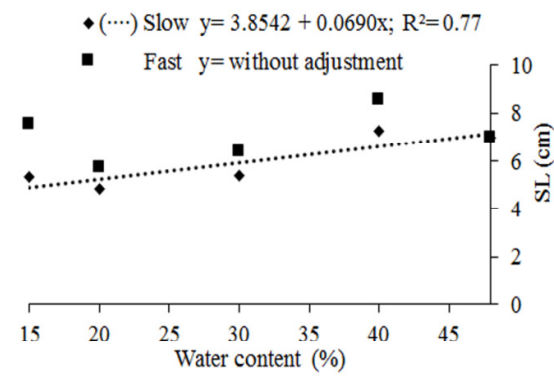

C)

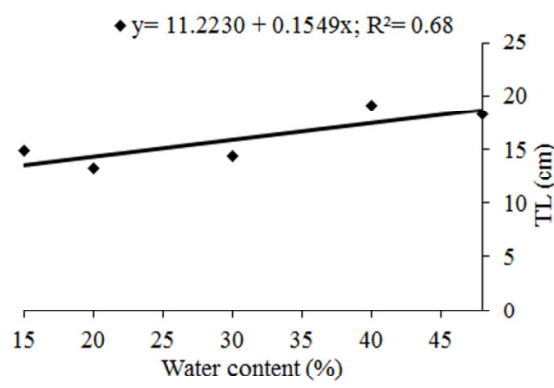

B)

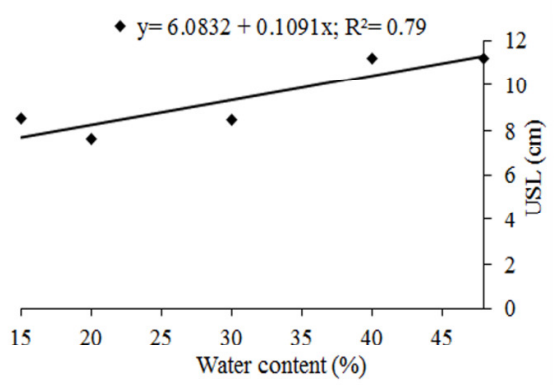

D)

- $y=0.000047+0.000565 x-0.000006 x^{2} ; R^{2}=0.84$

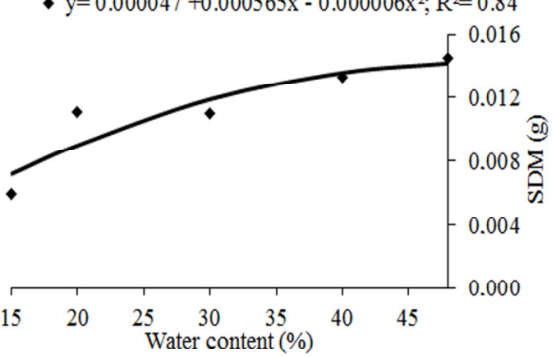

E)

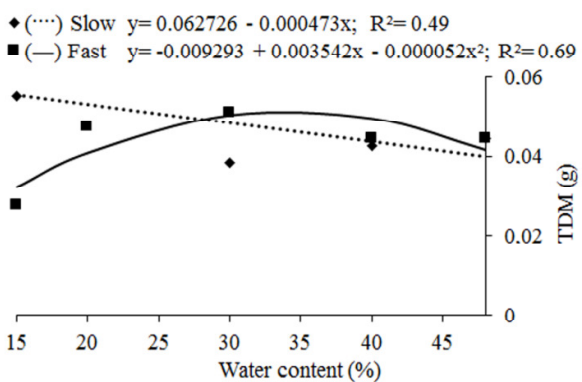

Figure 3. Shoot length (SL) (A), underground system length (USL) (B), total length (TL) (C), shoot dry mass (SDM) (D) and total dry mass (TDM) (E) of Hancornia speciosa seedlings subjected to fast and slow drying at different water contents.

To reduce the sensitivity to desiccation, a combination of fast desiccation and water content of $15 \%$ was used based on the results of the experiments on the effect of desiccation and water content.

Seeds that were not subjected to osmotic treatments and were dried to water content of $15 \%$ showed the best values for the primary root protrusion, normal seedling growth, and germination speed index $(74 \%, 56 \%$, and 1.444 , respectively) (Table 1 ).

Regarding the shoot length, the highest values were observed in seeds without osmotic treatment $(7.55 \mathrm{~cm})$ that not varied statistically from previously treated with PEG -0.1 MPa without ABA $(6.61 \mathrm{~cm})$ and PEG -0.3 MPa without ABA (6.91 $\mathrm{cm})$. The length of the underground system and total length and total dry mass of shoots did not differ significantly between the treatments, with the 
average of $9.93 \mathrm{~cm}, 16.21 \mathrm{~cm}$, and $0.0094 \mathrm{~g} \mathrm{~cm}$, respectively.

Table 1. Primary root protrusion (PRP), percentage of normal seedlings (NS), germination speed index (GSI), shoot length (SL), underground system dry mass (USDM) and total dry mass (TDM) of seedlings from $H$. speciosa seeds treated with polyethylene glycol (PEG) (6000) -0.1 and $-0.3 \mathrm{MPa}$, with or without abscisic acid (ABA), followed by fast desiccation to $15 \%$ water content.

\begin{tabular}{ccccccc}
\hline Treatments & PRP $(\%)$ & NS $(\%)$ & GSI & SL $(\mathrm{cm})$ & USDM $(\mathrm{g})$ & TDM $(\mathrm{g})$ \\
\hline $0 \mathrm{MPa}(-) \mathrm{ABA}$ & $74 \mathrm{a}^{*}$ & $56 \mathrm{a}$ & $1.444 \mathrm{a}$ & $7.55 \mathrm{a}$ & $0.0338 \mathrm{~b}$ & $0.0276 \mathrm{~b}$ \\
\hline$-0.1 \mathrm{MPa}(+) \mathrm{ABA}$ & $33 \mathrm{~b}$ & $32 \mathrm{~b}$ & $0.496 \mathrm{~b}$ & $5.02 \mathrm{~b}$ & $0.0276 \mathrm{~b}$ & $0.0348 \mathrm{~b}$ \\
$-0.1 \mathrm{MPa}(-) \mathrm{ABA}$ & $43 \mathrm{~b}$ & $37 \mathrm{~b}$ & $0.653 \mathrm{~b}$ & $6.61 \mathrm{a}$ & $0.0409 \mathrm{a}$ & $0.0489 \mathrm{a}$ \\
$-0.3 \mathrm{MPa}(+) \mathrm{ABA}$ & $48 \mathrm{~b}$ & $25 \mathrm{~b}$ & $0.734 \mathrm{~b}$ & $5.61 \mathrm{~b}$ & $0.0324 \mathrm{~b}$ & $0.0430 \mathrm{a}$ \\
$-0.3 \mathrm{MPa}(-) \mathrm{ABA}$ & $50 \mathrm{~b}$ & $35 \mathrm{~b}$ & $0.733 \mathrm{~b}$ & $6.91 \mathrm{a}$ & $0.0372 \mathrm{a}$ & $0.0498 \mathrm{a}$ \\
\hline $\mathrm{CV}(\%)$ & 18.7 & 23.2 & 17.2 & 13.5 & 9.2 & 11.7 \\
\hline
\end{tabular}

* Means followed by the same letter do not differ significantly from each other by $\mathrm{F}$ test at 5\% significance. (+) combined treatment with abscisic acid (ABA) and (-) not associated treatment with abscisic acid.

The highest biomass accumulation in the underground system was observed in seeds subjected to PEG -0.1 MPa (-) ABA (0.0409 g) and PEG -0.3 MPa (-) ABA (0.0372 g) (Table 1). With respect to the total dry mass, the osmotic treatments PEG -0.1 MPa (-) ABA (0.0489 g) and PEG -0.3 $\mathrm{MPa}(-) \mathrm{ABA}(0.0430 \mathrm{~g})$ and (+) ABA (0.0498 g) yielded the highest biomass accumulation in the seedlings.

\section{DISCUSSION}

The underground system of $H$. speciosa seedlings consists of cotyledons primary root and xylopodium. The latter presents a stem-like structure, which is consistent with the literature. which reports that the anatomical structure of xylopodium in some Brazilian Savanna species can be root-like stem-like or mixed (stem and root) (APPEZZATO-DA-GLÓRIA et al., 2008). The occurrence of these underground systems facilitates the storage of reserve compounds there by permitting for the species survival of unfavorable conditions in the Brazilian Savanna such as the dry season and frequent fires during the winter (RIZZINI; HERINGER, 1961; HAYASHI; APPEZZATO-DA-GLÓRIA, 2007).

The reduction of water content in $H$. speciosa seeds in the first $18 \mathrm{~h}$ was similar in both desiccation methods ( $30 \%$ water content). However, the silica gel (fast method) provided the most intense loss of water than the seeds desiccation in laboratory conditions (slow method). The method used to dry the seeds mainly influences the speed of water withdrawal at lower water levels $(20 \%$ and 15\%). In $H$. speciosa seeds from the municipality
João Pessoa (PB). desiccation under normal laboratory conditions (average temperature of $24.5 \pm$ $0.5{ }^{\circ} \mathrm{C}$ and average relative humidity of $78 \% \pm 3 \%$ ) reduced the water content from $56 \%$ to $31 \%$ after 72 $\mathrm{h}$ reaching $12 \%$ after $144 \mathrm{~h}$ (SANTOS et al., 2010).

The desiccation methods interfered with the germination of the seeds indicating the different levels of desiccation-sensitivity of seeds to water levels. More than $50 \%$ of normal seedlings had a water content of $15 \%$ after fast desiccation and 30\% after slow desiccation. To attain lower water-content levels seed desiccation should be performed at lower temperatures and within a short span of time (HONG and ELLIS, 1996) as seen with fast desiccation to $15 \%$ water content although it reduced the germination potential to $55 \%$. The reduction in the exposure time at intermediate levels of hydration minimizes the accumulation of damage associated with desiccation (WALTERS et al., 2001; WESLEY- SMITH et al., 2001).

The desiccation-sensitivity of $H$. speciosa seeds was evident from the seed germination results; therefore, desiccation to water contents of less than $15 \%$ and $30 \%$ by fast and slow desiccation methods. Respectively may be considered critical for the species. Therefore fast desiccation reduces the time in which the seeds are exposed to processes that are deleterious to their metabolism (PAMMENTER et al., 1999).

The negative effects of slow desiccation to less than $30 \%$ water levels were also observed in a study conducted by Masetto and Scalon (2014) $H$. speciosa seeds subjected to desiccation under laboratory conditions (slow) negatively affected the seed vigor with $30 \%$ root protrusion at 5\% water content. For the same species, Santos et al. (2010) observed that desiccation under normal laboratory 
conditions and less than $23 \%$ water content reduces the percentage of emergence and seedling vigor.

The length and total dry mass of seedlings were negatively affected by the desiccation of seeds in both desiccation methods. These results suggest that soil moisture influences the initial growth of seedlings; thereby seedlings grown from seeds with higher water content may display better development and consequently higher rooting and uptake of water and nutrients enabling the survival of the species in nurseries. The reduction in seedling length was also detected in $H$. speciosa Gomes seeds (SANTOS et al., 2010) and Eugenia pyriformis Camb. (uvaia) seeds (SCALON et al., 2012).

It was not possible to reduce the seed sensitivity to desiccation via fast desiccation. Seeds were viable only when they were not subjected to osmotic treatments. Possibly the use of these concentrations and seed incubation times were not sufficient to induce the protective mechanisms to stress caused by desiccation. Although the use of ABA whether associated with osmotic treatment does not contribute to the re-establishment of desiccation tolerance in germinated seeds of some species and desiccation-sensitive seeds (BUITINK et al., 2003; FARIA et al., 2005), in $H$. speciosa seeds the use of PEG associated with ABA during an incubation period of $120 \mathrm{~h}$ and further desiccation over silica gel to $15 \%$ water content did not reduce their sensitivity to desiccation.
Newly processed $H$. speciosa seeds primed for two days in PEG $6000(0.0 ;-0.2 ;-0.4$; and -0.6 $\mathrm{MPa}$ ) but not subjected to desiccation at low water levels displayed a decrease in germination speed and root length indicating that the priming did not improve seed vigor (MASETTO; SCALON, 2014).

Further studies should be conducted to test different desiccation conditions concentrations of PEG with or without ABA and incubation times in order to reduce the sensitivity to desiccation in $H$. speciosa seeds.

\section{CONCLUSIONS}

H. speciosa seedlings presents stem-like xylopodium structure.

The seeds are tolerant to water content reduction up to $15 \%$ with fast desiccation and $30 \%$ with slow desiccation methods.

Priming when associated with abscisic acid did not reduce the sensitivity to desiccation in $H$. speciosa seeds.

\section{ACKNOWLEDGEMENTS}

The authors acknowledge the Coordenação de Aperfeiçoamento de Pessoal de Nível Superior (CAPES), Programa Nacional de Pós- Doutorado (PNPD/CAPES-Projeto 2673/2011).

RESUMO: Objetivou-se neste trabalho descrever a germinação e avaliar a secagem e a redução da sensibilidade à dessecação em sementes de Hancornia speciosa Gomes. Inicialmente, foi realizada a descrição das características de germinação e aspectos morfofisiológicos das plântulas. Para primeiro experimento, as sementes foram submetidas à secagem rápida (sílica gel ativada) e à secagem lenta (condições de ambiente de laboratório) até atingirem os teores de água de 40, 30, 20 e 15 $\pm 2 \%$. Na tentativa da redução da sensibilidade à dessecação em um segundo experimento, as sementes foram embebidas em polietileno glicol (PEG) nos potenciais de $-0,1$ e $-0,3 \mathrm{MPa}$ por 120 horas associados ou não ao ácido abscísico (ABA) (10 $\left.{ }^{-4} \mathrm{M}\right)$ e posteriormente submetidas a secagem rápida no teor de água de $15 \%$, de acordo com os resultados do primeiro experimento. $\mathrm{O}$ potencial fisiológico das sementes, em ambos os experimentos, foi avaliado por meio dos testes de protrusão da raiz primária, porcentagem de plântulas normais, índice de velocidade de germinação, comprimento e massa seca de plântulas (parte aérea, sistema subterrâneo e total). As plântulas de $H$. speciosa apresentam xilopódio de estrutura caulinar. As sementes toleram a redução do teor de água até $15 \%$ na secagem rápida e de $30 \%$ para secagem lenta. O condicionamento osmótico não foi eficiente para reduzir a sensibilidade à dessecação de sementes de H. speciosa.

PALAVRAS-CHAVES: Mangaba. Tempo de secagem. Polietileno glicol. Ácido abscísico.

\section{REFERENCES}

ABUD, H. F.; REIS, R. G. E.; TEÓFILO, E. M. Caracterização morfológica de frutos, sementes, plântulas e germinação de Mucuna aterrima Piper \& Tracy. Revista Ciência Agronômica, Fortaleza, v. 40, n. 4, p. 563$569,2009$. 
ANDRÉO, Y.; NAKAGAWA, J.; BARBEDO, C. J. Mobilização de água e conservação da viabilidade de embriões de sementes recalcitrantes de ingá (Inga vera Will. subsp. affinis (DC.) T. D. Pennington). Revista Brasileira de Botânica, São Paulo, n. 29, p. 309-318, 2006.

APPEZZATO-DA-GLóRIA, B.; CURY. G.; SOARES. M. K. M.; ROCHA, R.; HAYASHI, A. H. Underground systems of Asteraceae species from the Brazilian Cerrado. Journal Torrey Botanical Societ, Lawrence, v. 135, p. 103-113, 2008. http://dx.doi.org/10.3159/07-RA-043.1

BARROS, D. I.; BRUNO, R. L. A.; NUNES, H. V.; CABRAL, G. C.; PEREIRA, W. E.; MENDONÇA, R. M. N. Métodos de extração de sementes de mangaba visando à qualidade fisiológica. Revista Brasileira de Fruticultura, Jaboticabal, v. 28, n. 1, p. 25-27, 2006.

BRASIL. Ministério da Agricultura, Pecuária e Abastecimento - Regras para análises de sementes. Ministério da Agricultura. Pecuária e Abastecimento. Secretaria da Defesa Agropecuária. Brasília. DF: Mapa/ACS. 399 p., 2009.

BEARDMORE, T.; WHITTLE, C. A. Induction of tolerance to desiccation and cryopreservation in silver maple (Acer saccharinum) embryonic axes. The Physiology, Victoria, v. 25, n. 8, p. 965-972. 2005.

http://dx.doi.org/10.1093/treephys/25.8.965

BERJAK, P; FARRANT, J. M.; PAMMENTER, N. W.; VERTUCCI, C. W.; WESLEY-SMITH, J. Current understanding of desiccation-sensitive (recalcitrant) seeds: Development, states of water and responses to dehydration and freezing. In: CÔME D. CORBINEAU F. Editors. Proceedings of the Fourth International Workshop on Seeds: Basic and applied aspects of seed biology. Paris: ASFIS; 1993, pp. 715-722.

BERJAK, P.; FARRANT, J. M.; MYCOCK, D. J.; PAMMENTER, N. W. Recalcitrant (homoiohydrous) seeds: the enigma of their desiccation sensitivity. Seed Science and Technology, Zurique,v. 18, n. 3, p. 297-310, 1990.

BERJAK, P.; PAMMENTER, N. W. From Avicennia to Zizania: seed recalcitrance in perspective. Annals of Botany, London, v. 101, n. 2, p. 213-228. 2008. http://dx.doi.org/10.1093/aob/mcm168

BUITINK, J.; VU, B. L.; SATOUR, P.; LEPRINCE, O. The re-establishment of desiccation tolerance in germinated radicles of Medicago truncatula Gaertn. seeds. Seed Science Research, Wallingford, v. 13, p. 273286, 2003. http://dx.doi.org/10.1079/SSR2003145

DAWS, M. I.; GARWOOD, N. C.; PRITCHARD, H. W. Prediction of desiccation sensitivity in seeds of woody species: a probabilistic model based on two seed traits in 104 species. Annals of Botany, London, v. 97, p. 667-674, 2006. http://dx.doi.org/10.1093/aob/mc1022

DOP, P.; GAUTIÉ, A. Manuel de tecnique botanique. 2.ed. Paris: Lamarre, 1928. 594p.

FARIA, J. M. R.; BUITINK, J.; LAMMEREN, A. A. M. van; HILHORST, H. W. M. Changes in DNA and microtubules during loss and reestablishment of desiccation tolerance in germinating Medicago truncatula seeds. Journal of Experimental Botany, Oxford, v. 56, n. 418, p. 2119-2130, 2005.

http://dx.doi.org/10.1093/jxb/eri210

HAYASHI, A. H.; APPEZZATO-DA-GLÓRIA, B. Anatomy of the underground system in Vernonia grandiflora Less. and $V$. brevifolia Less. (Asteraceae). Brazilian Archives of Biology and Technology, Curitiba, v. 50, n. 6, p. 979-988, 2007. http://dx.doi.org/10.1590/S1516-89132007000700009

HONG, T. D.; ELLIS, R. H. A protocol to determine seed storage behaviour. Rome: IPGRI, 1996. 55 p. (Technical Bulletin, 1). 
KERMODE, A. R; FINCH-SAVAGE, W. E. Desiccation sensitivity in orthodox and recalcitrant seeds in relation to development. In: BLACK, M.; PRITCHARD, H. W, editors. Desiccation and survival in plants: drying without dying. Wallingford, Oxon: CABI Publishing; 2002. pp. 149-184.

http://dx.doi.org/10.1079/9780851995342.0149

MAGUIRE, J. D. Speed of germination-aid in selection and evaluation for seedling emergence and vigor. Crop Science. Madison, v. 2, n .1, p. 176-177, 1962.

MASETTO, T. E.; SCALON, S. P. Q. Drying and Osmotic Conditioning in Hancornia speciosa Gomes Seeds. Floresta e Ambiente, Rio de Janeiro, v. 21, n. 1, p. 62-68, 2014.

MINISTÉRIO DO MEIO AMBIENTE (MMA). O Bioma Cerrado. 2013. Disponível em: http://www.mma.gov.br/biomas/cerrado. Acesso em: 10 de abril de 2015.

OLIVEIRA FILHO, A. T.; RATTER, J. A. Vegetation physiognomies and woody flora of the cerrado biome. In: The cerrados of Brazil (P.S. Oliveira \& R.J. Marquis. eds.). Columbia University Press. New York, p. 91-120, 2002.

PAMMENTER, N. W.; BERJAK, P.; WALTERS, C. The effect of drying rate and processes leading to viability loss in recalcitrant seeds. In: Recalcitrant seeds. (MARZALINA, M.; KHOO, K. C.; JAYANTHI, N.; TSAN, F. Y.; KRISHNAPILLAY, B.). pp. 14-24. Forest Research Institute Malaysia. Kuala Lumpur, 1999, pp. $14-24$.

PRITCHARD, H. W. Water potential and embryonic axis viability in recalcitrant seeds of Quercus rubra. Annals of Botany, London, v. 67, n. 1, p. 43-49, 1991.

RIZZINI, C. T.; HERINGER, E. P. Underground organs of plants from some southern Brazilian savannas with special reference to the xylopodium. Phyton, Horn, v. 17, p. 105-124, 1961.

SACANDÉ, M.; JOKER, D.; DULLOO. M.; THOMSEN, K. A. (Ed.) Comparative storage biology of tropical tree seeds. Roma: International Plant Genetic Resources Institute. 363p. 2004.

SANTOS, P. C. G; ALVES, E. U.; GUEDES, R. S.; SILVA, K. B.; CARDOSO, E. A.; LIMA, C. R. Qualidade de sementes de Hancornia speciosa Gomes em função do tempo de secagem. Semina: Ciências Agrárias, Londrina, v. 31, n. 2, p. 343-352, 2010. http://dx.doi.org/10.5433/1679-0359.2010v31n2p343

SCALON, S. P. Q.; NEVES, E. M. S.; MASETO, T. E.; PEREIRA, Z. V. Sensibilidade à dessecação e ao armazenamento em sementes de Eugenia pyriformis Cambess (Uvaia). Revista Brasileira de Fruticultura, Jaboticabal, v. 34, n.1, p. 269-276, 2012.

SOUZA, F. G.; FIGUEIREDO, R. W.; ALVES, R. E.; MAIA, G. A.; ARAÚJO, I. A. Qualidade pós-colheita de frutos de diferentes clones de mangabeira (Hancornia speciosa GOMES). Ciência e Agrotecnologia, Lavras, v. 31, n. 5, p. 1449-1454, 2007.

WALTERS, C.; PAMMENTER, N. W.; BERJAK, P.; CRANE, J. Desiccation damage: "accelerated aging" and metabolism in desiccation tolerant and sensitive seeds. Seed Science and Research, Wallingford, v. 11, n. 2, p. 135-148, 2001.

WESLEY-SMITH, J.; PAMMENTER, N. W.; BERJAK, P.; WALTERS, C. The effects of two drying rates on the desiccation tolerance of embryonic axes of recalcitrant jackfruit (Artocarpus heterophyllus Lamk.) seeds. Annals of Botany, London, v. 88, n. 4, p. 653-664, 2001. http://dx.doi.org/10.1006/anbo.2001.1519 